\title{
STUDIES ON AMBROSIA. IV. EFFECTS OF SHORT PHOTOPERIOD AND 'TEMPERATURE ON SEX EXPRESSION ${ }^{1}$
}

\author{
Kenneth L. Jones
}

Ambrosia elation was one of the species studied by Garner and Allard (1920) in the first work on photoperiodism. They found that plants grown under a 7-hour photoperiod for a month produced pistillate flowers almost exclusively when returned to natural conditions. A genetical interpretation of sex in $A$. elatior was given by the writer (1936a) which was followed (1936b) by evidence of the photoperiod altering some strains. Mann (1942) reported that $A$. trifida was modified in sex by short photoperiods. This species, unlike $A$. elatior, seldom shows sexual variation in nature. Mann states that "In $A$. trifida, on the other hand, length of photoperiods and number of photoinductive cycles have a pronounced effect on sex expression. Lacking experimental information, the uniformity in field plants would suggest that genetic factors a re of less importance in $A$. trifidd than in $A$. elatior." The writer (1943) pointed out that "The uniformity of A. trifida in the field may be as genetical in its causes as is the variability of $A$. elatior. From the environmental angle, the experimental work has not been comparable, but there is evidence that A. elatior of certain strains is alterable in sex."

The object of the present investigation was to determine (1) the relative effects of a short photoperiod on the sex expression in $A$. trifida and in known genetical strains of $A$. elatior, and (2) the effect of temperature during the dark period on A. trifida.

Material and methods.-Achenes of $A$. trifida and of two strains of $A$. elatior, namely, the truebreeding, monoecious $A$. elatior " $\mathrm{N}$ ", and the pistillate $A$. elatior " $\mathrm{P}$ " were after-ripened at $5{ }^{\circ} \mathrm{C}$. (Davis, 1930), germinated at $30^{\circ} \mathrm{C}$., and sown in the greenhouse, June 14, 1943. . Two-branched plants were obtained by removing the plumules above the cotyledons. The most uniform of these were selected and one branch was arranged so that it could be darkened independently of the other branch (fig. 1 and 2 ). One branch received 20 short days of 6 hours each, and the other the natural photoperiod which was at the keginning of the experiment on July 20, 14 hours and 53 minutes from sunrise to sunset. The branches were covered from 3:00 or 4:00 p.m. to 9:00 or 10:00 a.m. the following day. Treatments were started July 20 for twenty-nine plants of $A$. trifida 36 days old, and July 26 for twenty-seven $A$. elatior "N" and thirtynine $A$. elatior "P", each 42 days old. Fifty-three

1 Received for publication February 10, 1947.

Paper from the Department of Botany, University of Michigan, Number 734.

I am indebted to Dr. Josephine Burkette for the use of much of the photoperiod equipment which she had employed in other studies. I wish also to thank Professor R. H. Roberts for suggesting that the factor of temperature be checked in the experiments. entire two-branched plants of $A$. trifida and fiftyone of $A$. elatior "N" were exposed to 20 short days of 6 hours each beginning July 20. During the dark period the plants were placed in a dark room where the temperature varied from $21^{\circ} \mathrm{C}$. to $26^{\circ} \mathrm{C}$.

In 1945, whole, unbranched plants of $A$. trifida, 10 days old, were grown under 20 short days of 6 hours each beginning May 30. Four lots of 100 plants each received a different temperature during the dark period, viz., $5^{\circ}, 15^{\circ}, 20^{\circ}-25^{\circ}$, and $28^{\circ} \mathrm{C}$. The plants at $5^{\circ}$ and $15^{\circ} \mathrm{C}$. were placed in refrigerator rooms and those at $28^{\circ} \mathrm{C}$. in a culture room. These rooms have only double doors as outlets. The room at $20^{\circ}-25^{\circ} \mathrm{C}$. adjoins the greenhouse and the air is kept circulating between the two by a fan. During the period of light the plants were in the greenhouse at a temperature of $20^{\circ}-25^{\circ} \mathrm{C}$. The treatments ended June 18 when the plants were returned to natural light and temperature conditions.

In 1946, whole, two-branched and unbranched plants of $A$. trifida, 36 days old, were grown under 20 short days of 6 hours each beginning July 20 . Four lots of about fifty plants each received a different temperature during the dark period, viz., $5^{\circ}, 15^{\circ}, 21^{\circ}-25^{\circ}$, and $35^{\circ} \mathrm{C}$. in the rooms used in 1945. When exposed to light they were in the greenhouse at $20^{\circ}-30^{\circ} \mathrm{C}$. The treatments ended August 10 when the plants were returned to the greenhouse.

REsulTs. - 1943.-The plants were 36 to 42 days old at the beginning of the experiment. They were vegetative, macroscopically, but undoubtedly possessed floral primordia because floral buds appeared as early as 4 days on control branches. The results thus concerned the effect of the short photoperiod on floral development, not initiation.

Table 1 gives the degree of floral development at the end of the 20 six-hour days, before the plants were returned to natural light conditions. Entire, treated plants were dwarfed and unbranched. They ordinarily had mature pistillate heads in the axils of the leaves, but terminal floral buds were barely visible. Two plants of $A$. elatior " $\mathrm{N}$ " formed pistillate terminal racemes and hence were sex reversals (fig. 4). Where only one branch received short days, the plants were strikingly dimorphic (fig. 5). The treated branch was about one-half the height of the other and showed a marked maturing of lateral pistillate heads and a suppression of terminal staminate structures. The control branch usually had a terminal staminate bud but no lateral pistillate heads. Some plants of $A$. elatior " $\mathrm{P}$ " normally bear terminal pistillate inflorescences. These were usually accelerated in their growth by the short-days. 


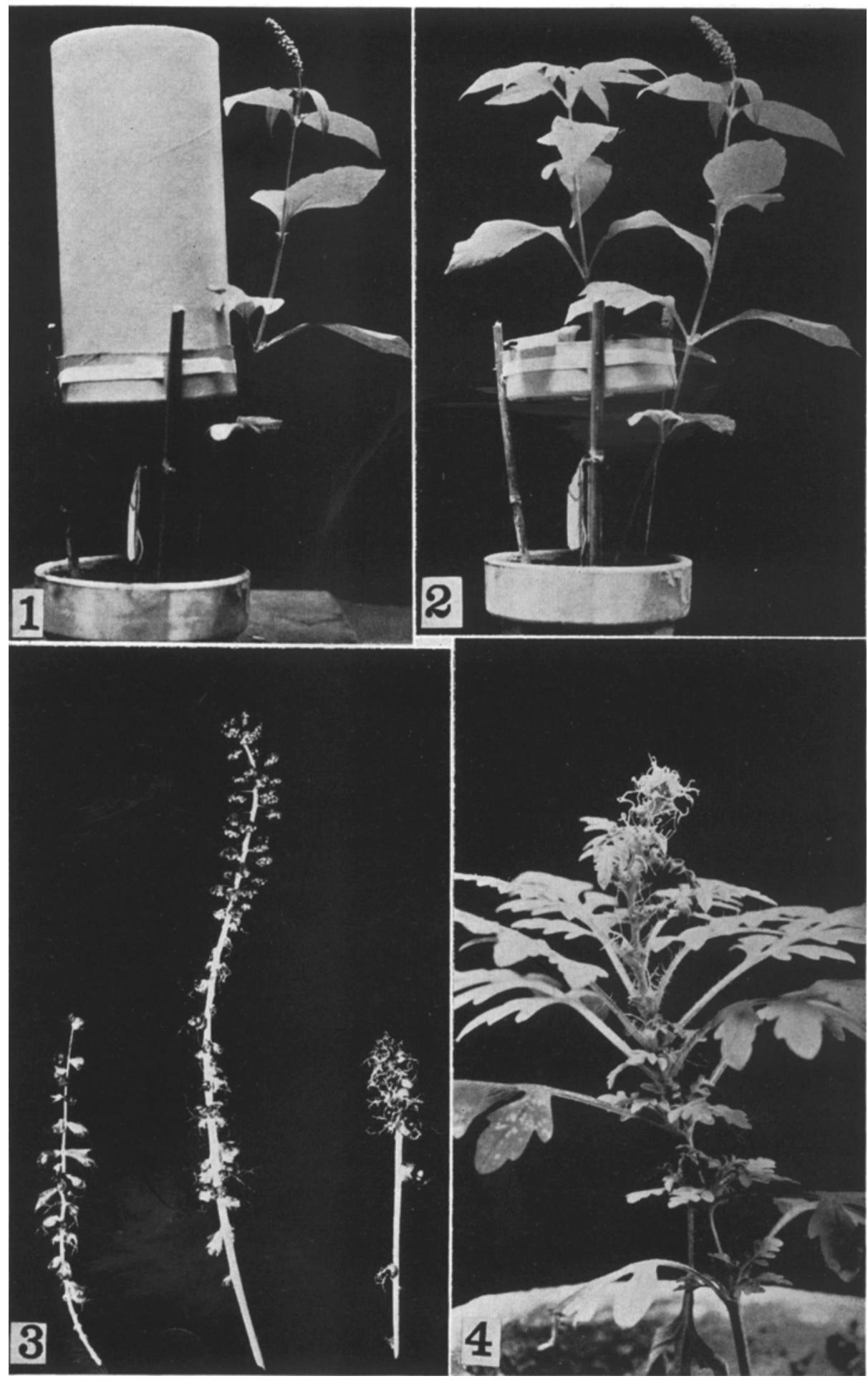

Fig. 1-4.-Fig. 1 and 2. A. trifida, showing method of shiclding one branch from light. Control branch has formed a staminate raceme.-Fig. 3. A. trifida racemes showing pistillate structures formed on short-day branches as aftereffects. The central raceme is androgynous, with the basal half mostly pistillate. The other two are entirely pistillate. -Fig. 4. A. elatior "N" which has undergone a sex reversal to the pistillate condition during the course of the short photoperiod treatments. 
'TABLE 1. The floral condition at the end of 20 sho.t-days of 6 hours each at about $20^{\circ}-30^{\circ} \mathrm{C}$. (1943).

\begin{tabular}{|c|c|c|c|c|c|c|c|}
\hline Plants & $\begin{array}{c}\text { Part } \\
\text { treated }\end{array}$ & $\begin{array}{l}\text { Number } \\
\text { of plants }\end{array}$ & $\begin{array}{l}\text { Number } \\
\text { plants } \\
\text { flowering }\end{array}$ & $\begin{array}{c}\text { Number } \\
\text { plants } \\
{ }^{\prime} \mathrm{TR}+\mathrm{P}\end{array}$ & $\begin{array}{l}\text { Number } \\
\text { plants } \\
\text { TR only }\end{array}$ & $\begin{array}{c}\text { Number } \\
\text { plants } \\
\text { P only }\end{array}$ & $\begin{array}{c}\text { Total } \\
\text { number } P\end{array}$ \\
\hline A. trifida & whole plant & 49 & 32 & 7 & 1 & 24 & 206 \\
\hline \multirow[t]{2}{*}{ A. trifida } & branch & 28 & control 28 & 6 & $2:$ & 0 & 35 \\
\hline & & & treated $\gtrsim 2$ & 10 & 0 & 12 & 138 \\
\hline A. elatior "N" & whole plant & 50 & 34 & 15 & 0 & 19 & $\begin{array}{l}1000 \\
\text { circa }\end{array}$ \\
\hline \multirow[t]{2}{*}{ A. elatior "N" } & branch & 26 & control 26 & 9 & 17 & 0 & 114 \\
\hline & & & treated 26 & 22 & 0 & 4 & 463 \\
\hline \multirow[t]{2}{*}{ A. elatior "P" } & branch & 30 & control 28 & 13 & 15 & 0 & 189 \\
\hline & & & treated 27 & 21 & 1 & 5 & 494 \\
\hline
\end{tabular}

TR-terminal raceme; recorded if macroscopically visible as a floral bud.

$P$ - pistils borne laterally in leaf axils; rccorded only where styles are evident.

After completion of the photoperiod experiment, the plants were placed in the greenhouse under natural light conditions, it being the season which coincided with the time of flowering for the genus. Final observations, made on September 13, are recorded in table 2. The most extreme changes occurred in whole plants of $A$. trifida which had grown under short days. Only two such plants were normal. The terminal racemes (and plants) were entirely pistillate in eight instances (fig. 3). Twenty-four individuals had intermediate racemes consisting of staminate and pistillate heads, and eighteen of these bore androgynous heads. Dissection of the androgynous heads disclosed that pistils replaced whole staminate flowers, stamens, or pistillodia. In two plants the pistillate structures in the axils' of leaves had changed to staminate.

Whole treated plants of $A$. elatior "N" showed similar modifications to the foregoing, although 39 per cent were unchanged and only 76 per cent matured terminal racemes. The transformation of staminate structures paralleled that of $A$. trifida, but there were no instances in which pistillate heads in the leaf axils changed to staminate. The two branches on whole plants grown under natural light were always identical in sex, but, curiously, this was not always true under the short days. Ten individuals of $A$. elatior "N" and three of $A$. trifida had branches bearing racemes of opposite sex.

Plants in which only one branch received short photoperiod often produced no raceme on the treated branch. The terminal floral buds died in sixteen out of twenty-two plants of $A$. elatior "N", in twelve out of twenty-two of $A$. elatior "P", and in six out of ten $A$. trifida. All plants of $A$. elatior " $N$ " which developed racemes were unchanged in sex; two plants of "P" were altered, one toward the pistillate and the other toward the staminate condition. All four plants of $A$. trifida which formed racemes underwent modification. In two plants of $A$. trifida there was evidence of the control branch being affected by the treatment given the other branch, as has been reported, for example, in Xanthium (Hamner and Bonner, 1938). These were normal except for a few pistillate heads on one lateral branch.

The short photoperiod caused the pistillate involucres to be incompletely formed, partially exposing the pistils (fig. 6). Mann's (1942, fig. 5, p. 785) illustrations show this clearly for $A$. trifida although no mention of it is made in the text. Axillary heads and the transformed ones in the terminal inflorescences showed the abnormality. It was very striking where the branches were given different light conditions. The untreated branch was always normal, whereas the change occurred in the short-day branch in six plants of $A$. elatior "P", nineteen of $A$. elatior "N", and thirteen of $A$. trifida. In whole treated plants, thirty-eight of $A$. trifida and thirty-four of $A$. elatior "N" had incompletely formed involucres. A single malformed in-

TARI.E. 2. Photoperiodic after-effects in plants recorded in table 1 returned to normal conditions (1943).

\begin{tabular}{|c|c|c|c|c|c|c|}
\hline Plants & $\begin{array}{c}\text { Part } \\
\text { treated }\end{array}$ & $\begin{array}{l}\text { Number } \\
\text { of plants }\end{array}$ & $\begin{array}{l}\text { Number } \\
\text { with MTR a }\end{array}$ & $\begin{array}{c}\text { Number } \\
\text { with MTR }{ }^{\star}\end{array}$ & $\begin{array}{c}\text { Number } \\
\text { with MTR } \zeta\end{array}$ & $\begin{array}{c}\text { Number } \\
\text { with MTR } q\end{array}$ \\
\hline A. trifida & whole plant & 45 & 34 & 2 & 24 & 8 \\
\hline \multirow{2}{*}{ A. trifida } & branch & 27 & control 27 & 25 & 2 & 0 \\
\hline & & & treated 4 & 0 & 4 & 0 \\
\hline A. elatior "N" & whole plant & 50 & 38 & 15 & 19 & 4 \\
\hline \multirow{2}{*}{ A. elatior "N" } & branch & 25 & control 25 & 25 & 0 & 0 \\
\hline & & & treated 6 & 6 & 0 & 0 \\
\hline \multirow[t]{2}{*}{ A. elatior " $P$ " } & branch & 26 & control 26 & 4 & 7 & 15 \\
\hline & & & treated 10 & 1 & $\mathcal{2}$ & 7 \\
\hline
\end{tabular}

aTR-mature terminal raceme, which may be: staminate $\left(\sigma^{*}\right)$, staminate and pistillate $(\zeta)$, or pistillate $(q)$. 
volucre often held two to six pistils, whereas in nature there is invariably only one.

1945.--The temperature during the dark period affects plant development markedly (Lewis and Went, 1945). Since the atmospheric temperatures for the short-day material and control were dissimilar, this factor was investigated. The temperature, as indicated by thermometer readings at any given time, within the carton shielding a branch and in the surrounding atmosphere was found not to vary more than $1^{\circ} \mathrm{C}$. However, since the dark period of a short-day branch included the relatively warm hours of late afternoon and early morning, the branch was then subjected to a temperature sometimes considerably higher than occurred during the natural dark period.

The effects of temperature were studied only on whole plants of $A$. trifida in which greatest alteration in sex had been secured. Negative results were obtained in 1945 from exposing young plants (10 days old) to different temperatures during the dark period. Following the treatments which ended $J$ une 18 , all plants were macroscopically vegetative. Pollination occurred August 15. All plants were normal with staminate racemes.

1946 - In 1946 older plants were used with lots of about fifty, at temperatures of $5^{\circ}, 15^{\circ}, 21^{\circ}-25^{\circ}$, and $35^{\circ} \mathrm{C}$. during the dark period. The results are recorded in tables 3 and 4 . Sex reversals from staminate to pistillate occurred at all temperatures. but were extreme at $15^{\circ} \mathrm{C}$. The withering of the staminate floral buds which was so pronounced an after-effect in 1943 took place again in high frequency at greenhouse temperatures $\left(21^{\circ}-25^{\circ} \mathrm{C}\right.$.).

$5^{\circ} \mathrm{C}$.-At $5^{\circ}$, as table 3 shows, this lot alone was macroscopically vegetative at the conclusion of the short day experiment. On August 27, after 17 days under normal conditions, most individuals had the staminate racemes fully elongated. The axillary pistillate flowers were more advanced than were ragweeds in nature at a corresponding stage; so that the differential acceleration of pistillateness, which takes place at natural summer temperatures during the short-day exposures, was present here as an after-effect. Table 4 shows that all plants formed terminal racemes. In fifteen plants, pistillate heads replaced staminate, but none were completely pistillate. Only four plants had the partially-formed involucres noted in 1943 .

$15^{\circ} \mathrm{C}$.-At the end of the short-day exposures, the terminal floral buds were barely visible and only one plant had mature axillary pistillate heads. On returning the plants to natural conditions, the shoots failed to elongate and fourteen of the seventeen staminate buds aborted. Table 4 indicates that only twenty-three ( 40 per cent) developed terminal racemes, and in all but one these underwent sex reversal. This is the highest percentage of sex re-
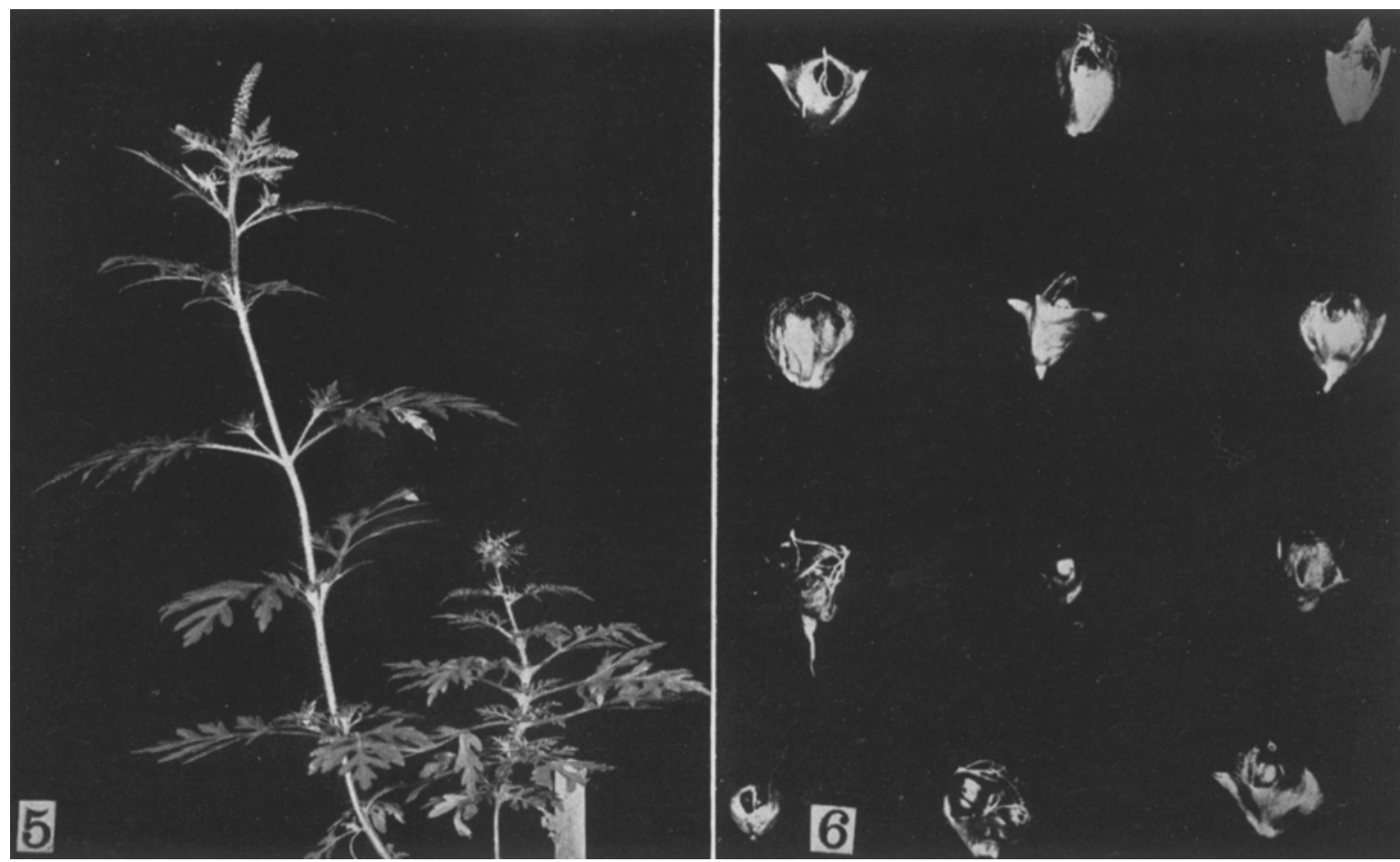

Fig. 5-6.-Fig. 5. A two-branched plant of A. elatior "N" after 20 six-hour short-day treatments. Control branch at the left has long internodes and staminate racemes. Treated branch has formed pistillate heads in the leaf axil but has formed no terminal raceme.-Fig. 6. Axillary pistillate heads from short-day branches of $A$. trifida. The head in the top row at the extreme right is normal, from a control branch. Note that the malformed involucres may enclose more than one pistil. 
TABLE 3. The floral condition in A. trifida at end of 20 short-days of 6 hours each at different temperatures during dark period (1946).

\begin{tabular}{|c|c|c|c|c|c|}
\hline Temperature & $\begin{array}{l}\text { Number } \\
\text { of plants }\end{array}$ & $\begin{array}{l}\text { Number plants } \\
\text { flowering }\end{array}$ & $\begin{array}{c}\text { Number plants } \\
\text { TR }+\mathbf{P}\end{array}$ & $\begin{array}{l}\text { Number plants } \\
\text { TR only }\end{array}$ & $\begin{array}{c}\text { Number plants } \\
\text { P only }\end{array}$ \\
\hline $5^{\circ} \mathrm{C}$ & 58 & 0 & 0 & 0 & 0 \\
\hline $15^{\circ} \mathrm{C}$ & 61 & 17 & 12 & 5 & 0 \\
\hline $21^{\circ}-25^{\circ} \mathrm{C}$ & 57 & 53 & 29 & 0 & 24 \\
\hline $35^{\circ} \mathrm{C}$ & 46 & 43 & 30 & 12 & 1 \\
\hline \multicolumn{6}{|l|}{ Control } \\
\hline Normal photoperiod & 40 & 32 & 0 & 32 & 0 \\
\hline
\end{tabular}

versal obtained in whole, treated plants. Malformed pistillate involucres were found in forty-eight plants.

$21^{\circ}-25^{\circ} \mathrm{C}$ - - This set, grown under atmospheric conditions similar to the control in the greenhouse, showed the same marked pistillate expression as was observed in the first experiment in 1943. At the end of the photoperiod treatments, all plants with macroscopically visible floral pärts possessed axillary pistils, twenty-four formed only pistils, whereas in the control only the terminal staminate structures were present. Four plants were pollinating and thirty-two had mature pistils. On returning to natural conditions the staminate buds aborted on eighteen plants. Only eleven plants developed racemes all of which were visible during short-day treatments.

$35^{\circ} \mathrm{C}$. - The plants at this temperature were the poorest developed vegetatively, but matured their flowers earliest. As table 3 shows, forty-three out of forty-six had macroscopic floral structures by August 10; of these, thirteen were pollinating and five had mature pistils. The development was not differentially pistillate as at the lower temperatures. The staminate buds aborted in seven plants. Sex reversals occurred in twelve individuals. Nine had incompletely formed pistillate involucres.

Control set (natural photoperiod and temperature).--The control set showed the early development of staminate racemes which is characteristic of $A$. trifida in nature. On September 13 these plants were about the same height as the $5^{\circ} \mathrm{C}$. set, the tallest of the short-day group; however, the latter exceeded them considerably in dry weight.
All plants had staminate racemes. In two plants the pistillate involucres incompletely covered the ovary, an abnormality not seen previously except in shortday material.

Discussion.-One object of this study was to determine whether or not different genetical strains of $A$. elatior would be altered in sex by short photoperiod treatments in the manner that Mann (1942) found to be true for $A$. trifida. The results confirm Mann's work and show that similar effects, perhaps not quite as frequent in occurrence, are produced in $A$. elatior. The conflicting accounts in the literature were due to non-parallel experiments. For example, the writer had never secured sexual changes in certain strains of $A$. elatior because the plants were kept under a short photoperiod. Had they been placed under a long photoperiod, following several photoinductive cycles, the after-effects secured by Garner and Allard (1920) in A. elatior and Mann (1942) in $A$. trifida would have undoubtedly appeared.

Under normal summer temperatures $\left(20^{\circ}-30^{\circ} \mathrm{C}\right.$.) plants 36 days old when given 6 -hour photoperiod for 20 days usually had the development of pistillate structures stimulated and staminate retarded. When returned to natural day, the staminate buds often aborted, or if they grew sex reversal frequently occurred. Vegetative growth was not resumed. The pistils were borne atypically in clusters, with each cluster partially enclosed within a malformed involucre. Some set seed even in cases of sex reversal.

The effects of treating only a portion of a plant had not been studied previously in Ambrosia. The

TABLE 4. Photoperiod after-effects in plants recorded in table 3 returned to normal conditions (1946).

\begin{tabular}{|c|c|c|c|c|c|c|c|}
\hline $\begin{array}{l}\text { Tempera- } \\
\text { ture }\end{array}$ & $\begin{array}{c}\text { Number } \\
\text { of } \\
\text { plants }\end{array}$ & $\begin{array}{c}\text { Number } \\
\text { with } \\
\text { aborted TR }\end{array}$ & $\begin{array}{l}\text { Per cent } \\
\text { aborted } \\
\text { TR }\end{array}$ & $\begin{array}{c}\text { Number and } \\
\text { per cent } \\
\text { with MTR }\end{array}$ & $\begin{array}{c}\text { Number and } \\
\text { per cent } \\
\text { with MTR }{ }^{\star}\end{array}$ & $\begin{array}{c}\text { Number } \\
\text { with } \\
\text { MTR } \Varangle\end{array}$ & $\begin{array}{c}\text { Number } \\
\text { with } \\
\text { MTR }\end{array}$ \\
\hline $5^{\circ} \mathrm{C}$ & 58 & 0 & $0 \%$ & $58(100 \%)$ & $43(74 \%)$ & 15 & 0 \\
\hline $15^{\circ} \mathrm{C}$ & 57 & 14 & $82 \%$ & $23(40 \%)$ & $1(4 \%)$ & 19 & 3 \\
\hline $21^{\circ}-25^{\circ} \mathrm{C}$ & 53 & 18 & $62 \%$ & $11(20 \%)$ & $5(45 \%)$ & 5 & 1 \\
\hline $\begin{array}{l}35^{\circ} \mathrm{C} \text {. } \\
\text { Control } \\
20^{\circ}-30^{\circ} \mathrm{C} \text {. } \\
\text { Normal }\end{array}$ & $4 \mathscr{2}$ & 7 & $16 \%$ & $38(90 \%)$ & $26(68 \%)$ & 9 & 3 \\
\hline photoperiod & 40 & 0 & $0 \%$ & $40(100 \%)$ & $40(100 \%)$ & 0 & 0 \\
\hline
\end{tabular}


floral development of a short-day branch differed in no fundamental respect from that of a whole shortday plant. Generally speaking, the changes produced in the treated branch did not appear in the other branch. However, no experiments were carried out where the control branch was defoliated.

The differential acceleration of pistillate development by short photoperiod has been reported previously (e.g., Schaffner, 1927, for Zea mays; Edmond, 1930, for Cucumis satious; Kirichenko and Bassarskaja, 1934, for Triticum erythrospermum according to Loehwing, 1938; and Naylor, 1941, for Xanthium pennsylvanicum). Sex reversal as described here for Ambrosia was primarily an after-effect of short-day treatments although there were instances within the course of the experiment. Most of the reports on this phenomenon induced by short-day conditions show pistillate expression. There are exceptions as in hemp where Schaffner (1923) found, "During December about $90 \%$ or more of both carpellate and staminate individuals show sex reversal."

Roberts and Struckmeyer (1938, 1939), in particular, have shown the need for taking into account the role of temperature in interpreting the results from photoperiod experiments. In regard to the present problem of the development of flowers in monoecious plants these authors cite one of the few records so far reported. They found (1939) that at $15^{\circ}-18^{\circ} \mathrm{C}$. Zea mays plants "in long days frequently produced androgynous tassels and poor ears, and plants in short days develop abortive tassels but have nearly normal-appearing ears." The response in Ambrosia as an after-effect of short days at $15^{\circ} \mathrm{C}$. was similar in that the staminate inflorescences aborted and pistillate formation was accelerated.

The reversal from staminate to pistillate condition and the abortion of staminate buds, which were macroscopically visible during the course of the short-day exposures, occurred at all temperatures used, but especially at $15^{\circ}$ and $21^{\circ}-25^{\circ} \mathrm{C}$.

\section{SUMMARY}

Ambrosia trifida and the normal strain of $A$. elatior are strictly monoecious in nature with the pistillate heads borne laterally in leaf axils and the staminate heads produced in terminal racemes. The pistillate strain of $A$, elatior includes some individuals with pistillate racemes.

Plants were grown for experiment and check as two-branched individuals. In some lots the entire plants and in others one branch were given 20 successive short days of 6 hours each. They were 36-42 days old at the start of the experiment and had already formed floral primordia. Following treatment they were returned to light conditions which prevail in nature at the time when $A m b r o s i a$ flowers.

The development of the pistillate flowers was accelerated and of the staminate flowers retarded by the short days.

The after-effects of short photoperiod exposures were similar in the two species, although less marked in $A$. elatior. Pistillate flowers replaced staminate in the terminal inflorescences even to the extent of the plants becoming entirely pistillate. Some of the seed produced by sexually reversed pistils were viable. The pistillate flowers in the leaf axils were often in clusters of two to six, partially enclosed in a malformed involucre. In two plants of $A$. trifid $a$ these heads were androgynous.

There was little evidence of a transfer of stimuli affecting flowering from a treated branch to a control branch; however, the controls were not defoliated.

Staminate buds, developed during the experiment, often aborted when the plants were returned to natural light conditions. 'This was more common among the single-treated branches than among whole plants. Some factor other than the photoperiod, such as a higher temperature within the carton shielding the branch during the treatment, may have accentuated the effect.

The effect of temperature during the dark period was investigated in whole plants of $A$. trifida. Sex reversals occurred as after-effects-at all temperatures employed $\left(5^{\circ}, 15^{\circ}, 21^{\circ}-25^{\circ}\right.$, and $35^{\circ} \mathrm{C}$. $)$, but at different frequencies. Staminate buds aborted especially at $15^{\circ}$ and at $21^{\circ}-25^{\circ} \mathrm{C}$. Staminate expression was stimulated at $35^{\circ} \mathrm{C}$.

\footnotetext{
Department" of Botany,

UNIVERSITY OF MTCHIGAN,

Ann Armor, Michlgan
}

\section{LITERATURE CITED}

Davis, W. E. 1930. Primary dormancy, after-ripening, and development of secondary dormancy in embryos of Ambrosia trifida. Amer. Jour. Bot. 17: 58-77.

Emmond, J. B. 1930. Seasonal variation in sex expression of certain cucumber varieties. Amer. Soc. Hort. Sci. Proc. 27: 329-332.

Garner, W. W., and H. A. Alrard. 1920. Effect of the relative length of day and night and other factors of the environment on growth and reproduction in plants. Jour. Agric. Res. 18: 553-606.

Ham Ner, K. C., and J. Bonner. 1938. Photoperiodism in relation to hormones as factors in floral initiation and development. Bot. Gaz. 100:388-431.
Jones, K. L. 1936a. Studies on Ambrosir. I: The inheritance of floral types in the ragweed, Ambrosia elatior L. Amer. Midl. Nat. 17:673-699.

- 1936b. Studies on Ambrosia. II : Effect of certain environmental factors on floral development of Ambrosia elatior. Bot. Gaz. 98: 296-305.

. 1943. Studies on Ambrosia. II I : Pistillate $A m$ brosia elatior $\times A$. trifida and its bearing on matroclinic inheritance. Ibid. 105:226-231.

Kirichenko, F. S., and M. A. Bassarskaja. 1934. Aspects of phasic development in wheat. Semenovodstvo. $4: 22-25$. 
Lewis, H., ANd F. W. Went. 1945. Plant growth under controlled conditions. IV: Response of California annuals to photoperiod and temperature. Amer. Jour. Bot. 32: 1-13.

Loenwixg, W. F. 1938. Physiological aspects of sex in angiosperms. Bot. Rev, 4: 581-625.

MaxN, L. K. 1942. Effects of photoperiod on sex expression in Ambrosia trifida. Bot. Gaz. 103: 780-787.

Naylor, F. L. 1941. Effect of length of induction period on floral development of Xanthium pennsylvanicum. Bot. Gaz. 103: 146-154.

Roberts, R. H., and B. Esther Struckmeyer. 1938.
The effects of temperature and other environmental factors upon the photoperiodic responses of some of the higher plants. Jour. Agric. Res. 56: 633-677.

__- AND _ 1939. Further studies of the effects of temperature and other environmental factors upon photoperiodic responses of plants. Jour. Agric. Res. 59 : 699-709.

Schaffare, J. H. 1923. The influence of relative length of daylight on the reversal of sex in hemp. Ecology $4: 323-334$

-1927. Control of sex reversal in the tassel of Indian corn. Bot. Gaz. $84: 440-449$.

\title{
STRUCTURES CORRESPONDING TO APPRESSORIA AND SUBSTOMATAL VESICLES PRODUCED ON NUTRIENT-SOLUTION AGAR BY CEREAL RUSTS ${ }^{1}$
}

\author{
Annie M. Hurd-Karrer and H. A. Rodenhiser
}

Germ Tubes from urediospores of cereal rusts germinated on nutrient-solution agar have produced bodies whose shape and mode of development identify them as structures corresponding to appressoria and substomatal vesicles. These structures have not heretofore been known to develop on artificial media.

Pole Evans (1907) described the appressoria and substomatal vesicles of nine species of Puccinia from stained sections of host tissues and concluded that the vesicle is morphologically distinct for each species. The bodies described in the present paper for six of these species- $P$. graminis tritici Eriks. and Henn.; $P$. triticina Eriks. (P. rubigo-vera tritici (Eriks. and Henn.) Carleton); $P$. dispersa Eriks. and Henn.; $P$. coronata avenae Fraser and Led. ( $P$. coronifera avenae Eriks.) ; $P$. hordei Otth ( $P$. simplex (Koern.) Eriks. and Henn., $P$. anomala Rostr.); and $P$. sorghi Schw.-also differ characteristically; and all but one ( $P$. hordei) conform closely to Pole Evans' descriptions and drawings of the substomatal vesicle of the species as it grows within the substomatal chamber of the host plant.

MEтHoDs.-Urediospores were dusted by means of a camel's-hair brush on the surface of freshly poured nutrient-solution agar about $2 \mathrm{~mm}$. thick in small petri dishes, and incubated from 1 to several days at room temperatures, $20^{\circ}-25^{\circ} \mathrm{C}$, or at refrigerator temperatures as low as $13^{\circ} \mathrm{C}$. Germination and growth were fairly rapid so that contaminating organisms rarely interfered with the observations.

For the nutrient medium, glucose was added to a dilution of a mineral-nutrient solution similar ${ }^{2}$ to one used for water cultures of cereal seedlings. The nutrient-solution agar contained: $\mathrm{M} / 5 \mathrm{MgSO}_{4}, 2.5$

${ }^{1}$ Received for publication February 24, 1947.

Presented at the American Phytopathological Society meeting at Cincinnati, Ohio, December 30, 1946. (Abstract in Phytopath. 37: 13. 1947.)

${ }^{2} A$ relatively high concentration of the dibasic phosphate was used to increase the buffer capacity and maintain a higher $p H$ value during autoclaving. cc.; $\mathrm{M} / 2 \mathrm{NH}_{4} \mathrm{NO}_{3}, 0.5$ cc.; $\mathrm{M} / 2 \mathrm{Ca}\left(\mathrm{NO}_{3}\right)_{2}, 1.5$ cc.; $\mathrm{M} / 5 \mathrm{KH}_{2} \mathrm{PO}_{4}, 1.5$ cc.; $\mathrm{M} / 5 \mathrm{~K}_{2} \mathrm{HPO}_{4}, 2.5$ cc.; 0.5 per cent $\mathrm{Fe}$ tartrate, 0.5 cc.; glucose, 20-60 g.; distilled water to make $1000 \mathrm{cc}$; agar, $20 \mathrm{~g}$. This medium was autoclaved for 10 minutes at 12 pounds pressure. Its reaction after autoclaving was near $p \mathbf{H} 6.0$.

Descriptions. - General.-About 15 hours, sometimes longer, after the spores were sown on the agar, the end or lateral branch of an occasional germ tube, possibly one in a thousand, swells and becomes densely filled with protoplasm containing orange-brown granules. At the base of the swollen tip, a septum is formed back of the advancing protoplasm. The swollen end may become lobed. Subsequent developments indicate that this structure is homologous with the appressorium that forms over a stoma of the host plant. It is referred to herein as the primary vesicle.

A small protuberance from this primary vesicle develops into a stalk, somewhat variable in length, which corresponds to the "penetration tube." On this stalk is formed a body whose shape and subsequent development indicate it to be homologous with the substomatal vesicle. It is referred to herein as the secondary vesicle.

More than one protuberance may grow from the primary vesicle but only one develops into a stalk and secondary vesicle. In some species extra protuberances may become fairly long and may have a septum at the base.

The contents of the primary vesicle move out through the stalk into the developing secondary vesicle. The now-empty primary vesicle has a clear bluish cast that sharply differentiates it from the empty hypha back of the cross wall. The secondary vesicle is deeply colored by the dense accumulation of orange-brown material, which becomes concentrated in bands when vacuolation occurs.

From the secondary vesicle the protoplasmic contents move into one or more slender hyphae, which may become banded with the orange-brown mate- 